\title{
PLANNING FOR ADVERTISEMENT DEVICES: A CASE STUDY OF BHOPAL
}

\author{
Vibhore Bakshi ${ }^{1}$ \\ ${ }^{1}$ Assistant Professor, Architecture and Planning Department, Amity University, Gurgaon
}

\begin{abstract}
Outdoor Media is one of the most opted modes of brand promotion. Billboard advertising is one of the most widely adopted forms of outdoor advertising. Outdoor media has seen an unprecedented growth in the recent years. This has increased with such a pace that it has resulted in encroachment of the area. These encroached land for advertisement devices is a major concern as it give rise to various issues related with pedestrian safety, motorist safety and spoiled streetscape. This research aims to formulate an action plan for proper regularization of advertisement devices in selected site of Bhopal based up on different characteristics. The outcome of research shall be an action plan of Advertisement Devices incorporating proper physical orientation and there placements at regular intervals preventing any visual clutter and increasing the road safety for motorist pedestrians and other affected groups.
\end{abstract}

Keywords: Encroached Land, Edestrian Safety, Motorist Safety, Action Plan, Visual Clutter, Road Safety

\section{INTRODUCTION}

Advertisement devices over the years have seen many innovations and the media landscape now forms an integral part of an urban landscape and infrastructure. These devices have an important role in present day life as it adds positively to the city character in terms of visual appeal, tourism, directional signage, information signage and the development of city infrastructure without putting additional strain on the Government. However if left uncontrolled it can also have a negative impact on the city

In the year 2011, the total size of the Indian advertising industry stood at about Rs 26,000 crore, recording a growth of 8 per cent. The growth rate for the year 2012 has been projected at $8-10 \%$. As per industry standards outdoor advertising accounts for nearly $5-6 \%$ of this revenue.

Municipal Corporations collects and taxes and revenue share from the advertising display put on the outdoor media sites. As compared to other means of revenue, organized Advertisement revenue collection has emerged as one of the fastest growth areas for the Corporations and has the potential to be among the top three revenue earners. Outdoor media in its present form has been contributing positively towards development of a better public infrastructure, it can also be of appeal to tourists visiting a city if promoted in a controlled and valid manner. Outdoor media has proved to be a very effective media for the promoting social and public awareness programs. Cities worldwide are following an integrated plan which ensures that this media of mass appeal offers the same level of visibility to social and public awareness messages when compared to commercial form of advertising. Outdoor media through the financing option of a public private partnership has been providing better public conveniences in a number of cities in the world. The outdoor media primarily thrives on catching the attention of road users both motorized and non-motorized as such it is at times

\subsection{Research Question and Aim}

The research question in the process is "Do advertisement devices are placed with a proper orderliness "?

The thesis aims "To formulate an action plan for proper regularization of advertisement devices in selected site of Bhopal based up on different characteristics". It requires the assessment of Road safety aspect, Physical

\subsection{Objectives}

Objective 1: To examine the provisions of MP advertisement policy, Delhi advertisement policy and other selected policies

Objective 2: To examine the scenario of advertisement in the selected site.

Objective 3: To examine the possibilities of regulating the different modes of outdoor advertisements at the selected site and plan for the same.

The study provides an understanding of the present condition of advertisement devices such as hoardings, public toilets, unipole advertisements, lamp pole advertisement; kiosk etc. The study focuses on the MP Nagar zone-1 area of Bhopal 
which is an example of commercial, public places and major road intersections as mentioned in objective 2 .

\subsection{Site Selection}

The research study area shall be MP Nagar Zone 1.The reasons for selecting MP Nagar as thesis sites are:

- M P Nagar zone 1 has a characteristics which covers a commercial area, major stretch.

- $\quad$ Located in front of the most renowned DB City Mall so the advertisers have tried their best to utilize the area in terms of advertisements.

- It covers a wide range of Advertisement devices such as public toilets, billboard etc.

- The advertisements devices are placed in a very irregular pattern

- The sizes of hoardings are not based on a definite format

\subsection{Scope and Limitation}

The scope of work addresses the statutes for advertisement devices by reviewing the literature review across the states and overseas. It involves selection of a commercial site at Bhopal and carrying out an opinion survey. The work focuses on the characterization of existing scenario of existing scenario of advertisement device in selected site. Preparation of an outdoor advertisement plan for the selected site for effective regularization. The study is limited to MP Nagar zone 1 in Bhopal. The study excludes Roof top advertisement. Wall paint advertisement other than on public utilities and temporary balloon advertisements etc.

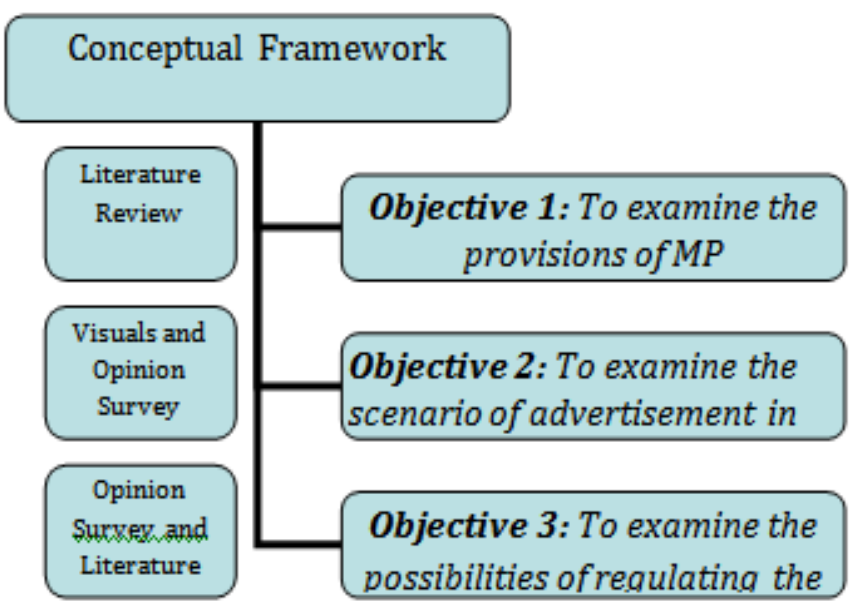

Fig 1: Conceptual Framework of research

\section{STUDY AREA}

\subsection{Selection of Site}

Bhopal district is almost $80 \%$ urbanized, with most people living in the city of Bhopal, as the principal city of region. It serves all towns and districts around .Basic infrastructure and the advertisement devices in the city are in problem. These problems will further grow unless measures and controls on development and regulation are not made in integrated manner. The advertisement situation in Bhopal is a serious concern especially in MP Nagar zone-1 due to concentration of activities. The highlighted ailments in the area are:

- Lack of Integration between land use and transport

- Lack of effective utilization of road system

- Lack of scientific placing of Bill boards

- Pedestrian safety due to improper heights of billboard from ground

- Motorist safety due to billboards

- Traffic congestion

- Lack of facilities and street furniture for pedestrian guidance

MP Nagar zone 1 is located in the central area of Bhopal which acts as major CBD area of Bhopal. A location map of MP Nagar zone 1 is shown below Until the initiation of Jawaharlal Nehru National Urban Renewal Mission (JNNURM) in 2005, little attention was given for the improvement of water supply infrastructure of Indian cities. Water sector constitutes highest number in terms of funding $(40 \%)$ and also the number of projects executed (HPEC, 2011). The water supply indicators are: 'coverage of water supply connections'; 'per capita supply of water'; 'extent of metering of water connections'; 'extent of non-revenue water'; 'continuity of water supply'; 'quality of water supplied'; 'efficiency in redressal of customer complaints'; 'cost recovery in water supply services'; and 'efficiency in collection of water supply-related charges'. 


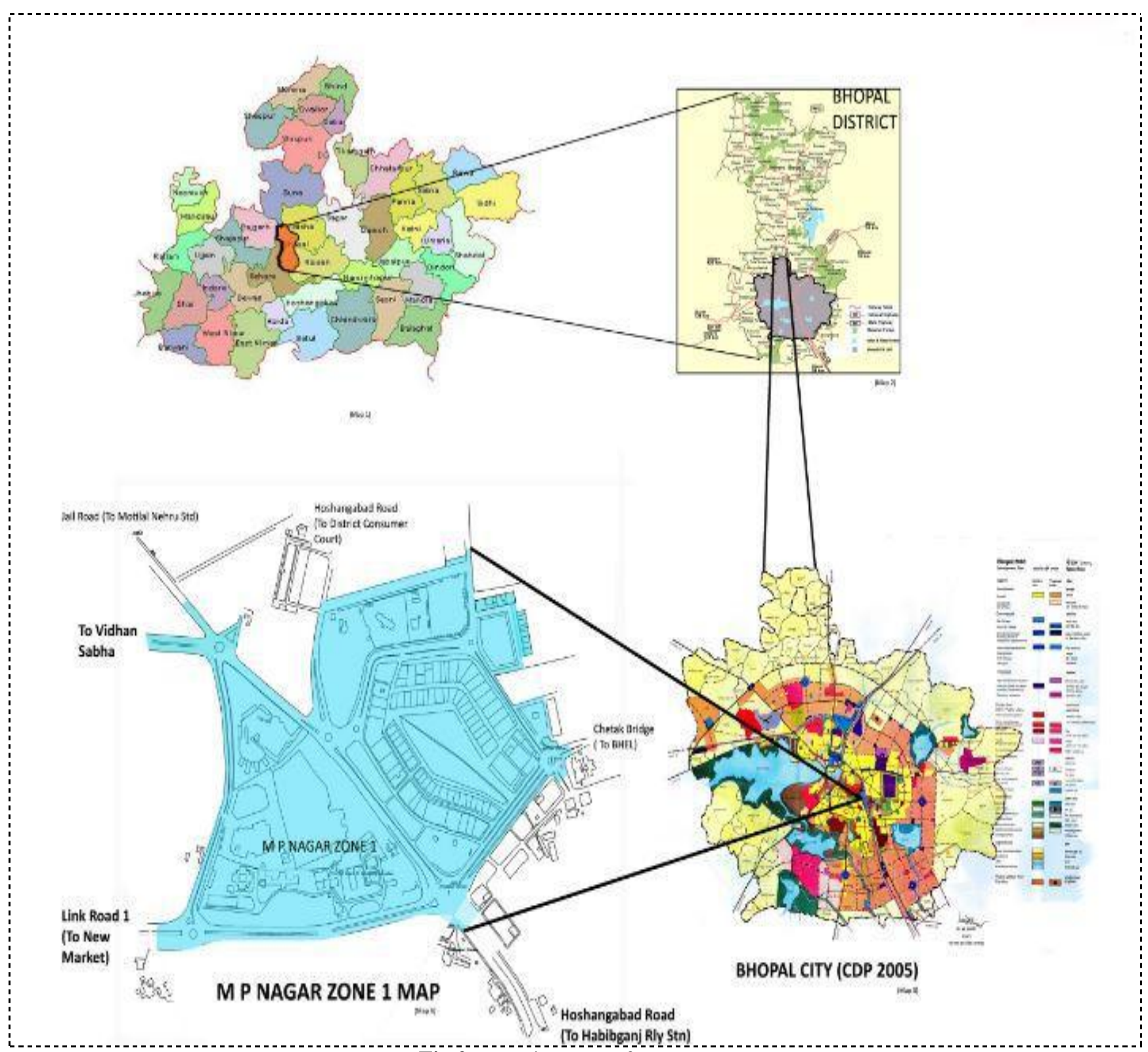

Fig 2: Location map of MP Nagar

\subsection{Scenario of Advertisement Devices at Bhopal}

\begin{tabular}{|l|l|}
\hline Category of device & Number of devices \\
\hline Hoarding & 1095 \\
\hline Roof top media & 210 \\
\hline Unipole advertisement & 30 \\
\hline Toilet blocks & 14 \\
\hline Kiosk & 80 \\
\hline
\end{tabular}

Source: Bhopal Municipal Corporation

There are a total of 1429 advertisement devices in Bhopal. Out of which 1095 are hoardings followed by 210 roof top advertisements further by kiosk, unipole advertisements and toilet blocks

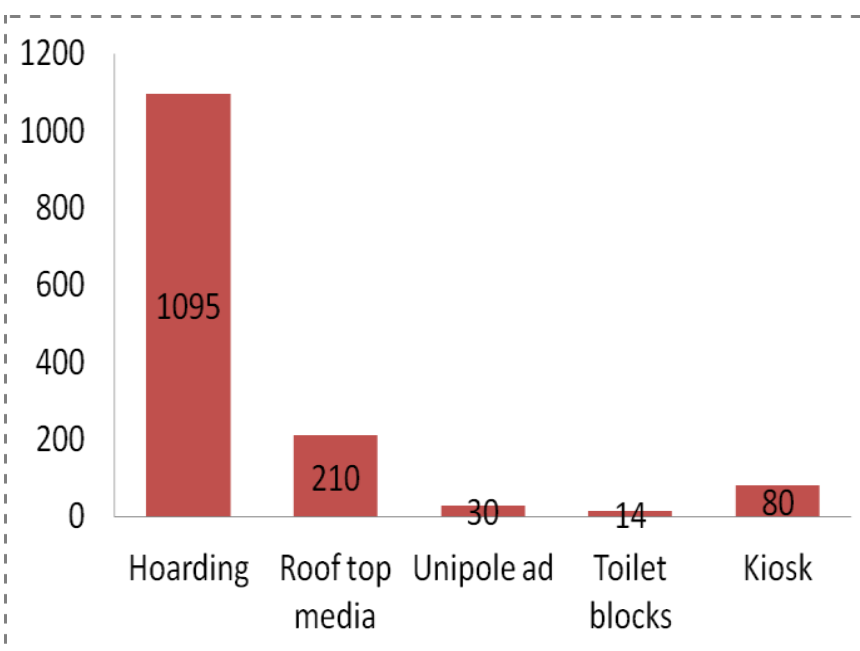

Bar Graph 1: No of different categories of advertisement devices (Bhopal) Source: Bhopal Municipal Corp 
The hoardings contribute to $77 \%$ followed by rooftop media which contributes to $15 \%$ further by kiosk (5\%), toilet blocks $(1 \%)$ and unipole advertisement $(2 \%)$.

\subsection{Advertisement Monitoring Agencies}

Nodal agencies which regulate advertisement activities through hoardings in Bhopal:

- Railway(regulate the whole railway area near Habibganj and Bhopal junction with no revenue sharing with other agencies

- $\quad$ BMC(Bhopal municipal corporation)

- BDA(Bhopal development authority)

- $\quad$ CPA(Capital project Assignment

\subsection{Scenario of Advertisement Devices at MP Nagar}

\section{Zone-1}

The surveyed area of site has 21 advertisement devices as shown in the map. Out of these the advertisements in the form of hoardings are maximum which contribute to 17 i.e. nearly $80 \%$ followed by 2 toilet blocks 1 kiosk and 1 gantry billboard.

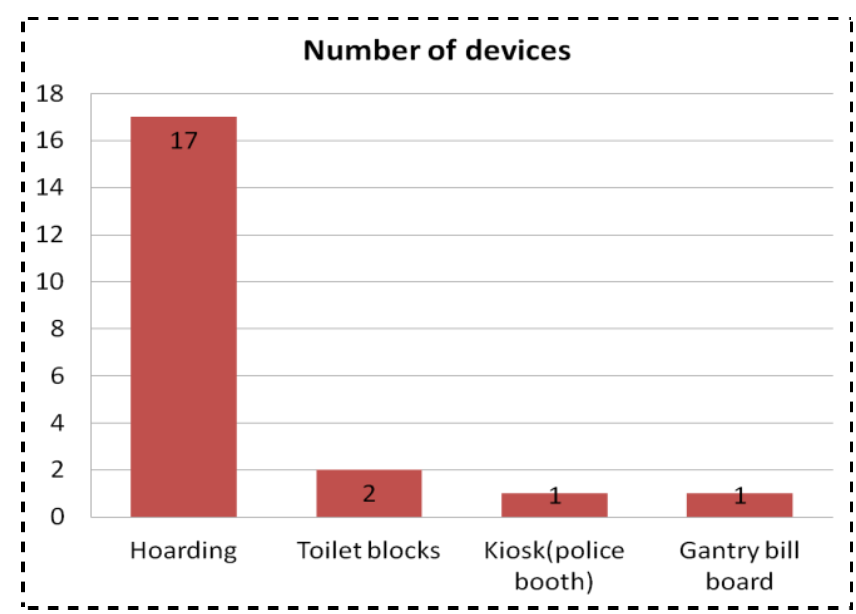

Bar Graph 2: No of different categories of advertisement devices (MP Nagar Zone-1) Source: Primary Survey

It is clear from the graph that advertisers have tried their best to seek the passerby's attention in the form of hoardings as they are maximum. For a planner the major thought of concern is the issues created by these advertisement devices so in the next chapter some parameters have been identified to address the issues generated by these advertisement devices.

The hoardings have been classified on the basis of surface area in to three types

- Small Hoardings: Hoardings having surface area between 4.4 meter square to 7.5 meter square. There are 8 small hoardings in surveyed area.

- Medium Hoardings: Hoardings having surface area between 8.9 meter square to 13.5 meter square. There are 5 medium small hoardings in surveyed area

- Large Hoardings: Hoardings having surface area between 15 meter square to 30 meter square. There are 4 large hoardings in surveyed area

\section{PARAMETERS IDENTIFICATION}

\begin{tabular}{|l|l|l|}
\hline $\begin{array}{l}\text { Sr } \\
\text { No }\end{array}$ & $\begin{array}{l}\text { Identified } \\
\text { Parameters }\end{array}$ & Related Issues \\
\hline $\mathbf{1}$ & $\begin{array}{l}\text { Physical } \\
\text { orientation }\end{array}$ & Distraction to drivers \\
\hline $\mathbf{2}$ & $\begin{array}{l}\text { Dimension of } \\
\text { hoarding(length, } \\
\text { width \& height } \\
\text { from ground) }\end{array}$ & $\begin{array}{l}\text { Irregular L/B ratio marc the } \\
\text { streetscape }\end{array}$ \\
$\begin{array}{l}\text { In most of the cases the height } \\
\text { of the hoarding is 1.2-1.3 } \\
\text { meters. }\end{array}$ \\
\hline
\end{tabular}

An Individual has to bent beneath the hoarding

3 Composition of Too much pictures Advertisement ,misrepresent the facts and causes visual clutter

4 Position of device The position of device should not be such that it affects the pedestrian passage

5 Compatibility of Advertisement devices are device with placed irrespective of the surroundings natural character of the place

6 Duration of Election posters are placed at devices(Election encroached spaces even on the poster) buildings. Political advertisements are placed more than the period of duration

7 Spatial location of $\quad$ The devices are located devices( Zoning irrespective of a dedicated zone Exercise for a particular dimension range of hoardings

Source: Primary Survey 


\section{ILLUSTRATIONS OF EXISTING CONDITION}
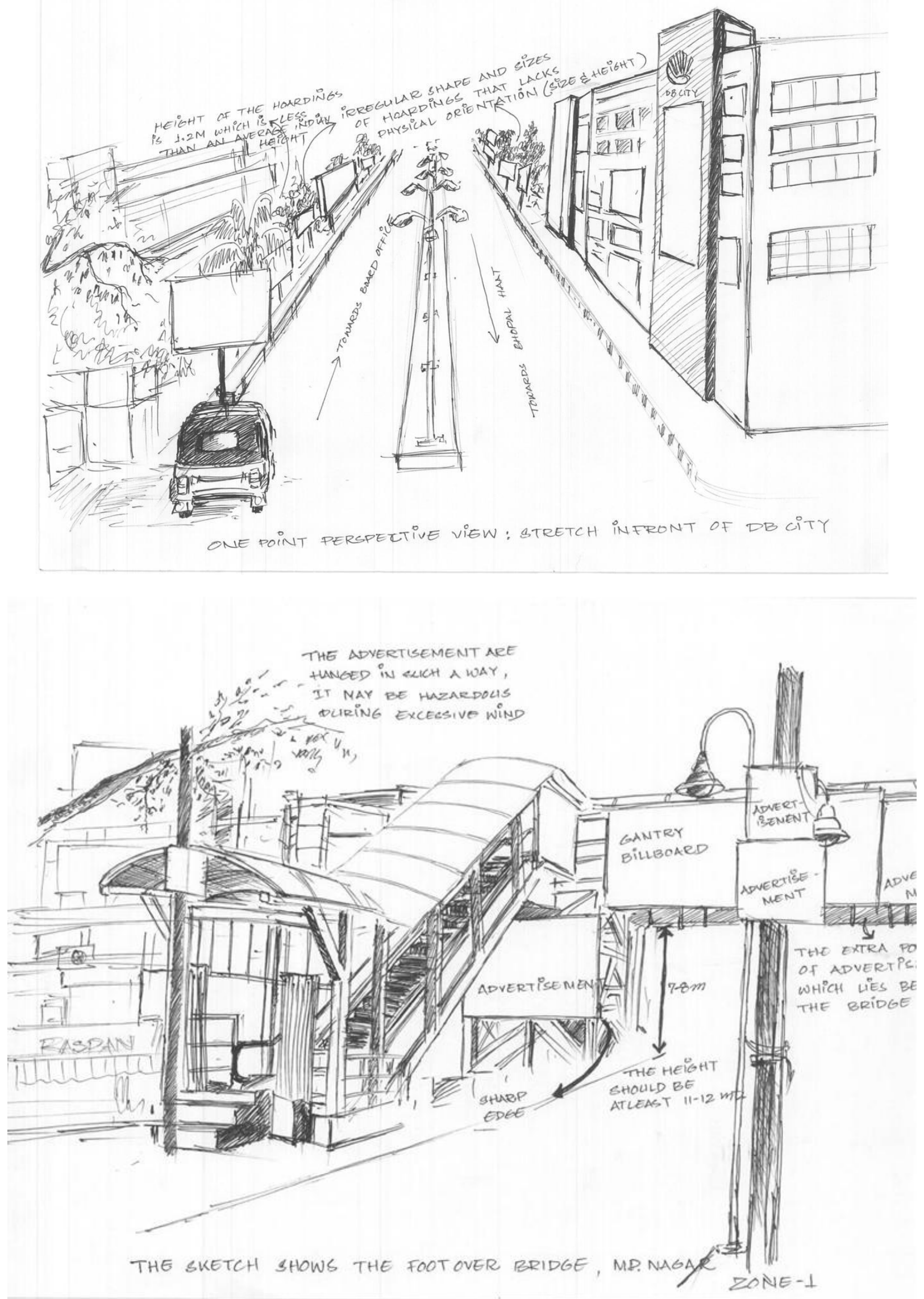
5. SUGGESTED STRATEGIES FOR ISSUES

\begin{tabular}{|c|c|c|c|c|c|}
\hline $\begin{array}{l}\text { Sr. } \\
\text { no }\end{array}$ & Parameters & Mode of Study & Suggested strategies & Adopted strategies & Reason \\
\hline \multirow[t]{2}{*}{1} & Physical orientation & Through visuals & $\begin{array}{lr}\cdot \text { Placing } & \text { small } \\
\text { advertisements } & \text { at } \\
\text { narrow } & \text { roads } \\
\text { especially at corners }\end{array}$ & $\begin{array}{l}\cdot \text { Placing of } \\
\text { advertisement between } \\
20 \text { deg-30deg of the } \\
\text { curve }\end{array}$ & $\begin{array}{l}\text { It is the most feasible } \\
\text { solution to decrease } \\
\text { distraction and } \\
\text { increase the sight } \\
\text { distance }\end{array}$ \\
\hline & (Angular position) & & $\begin{array}{l}\text {-Placing of } \\
\text { advertisement between } \\
20 \text { deg-30deg of the } \\
\text { curve }\end{array}$ & $\begin{array}{l}\text { - A car should cross a } \\
\text { curve within } 2.5 \\
\text { seconds }\end{array}$ & \\
\hline 2 & $\begin{array}{l}\text { Dimension of } \\
\text { hoarding(length, } \\
\text { width \& height from } \\
\text { ground) }\end{array}$ & $\begin{array}{l}\text { Through visuals and } \\
\text { detailed sketches }\end{array}$ & $\begin{array}{l}\text { - } \mathrm{L} / \mathrm{B} \text { ratio should be } \\
\text { between } 1.414 \text { to } \\
1.616 \text { which is a ratio } \\
\text { of } \mathrm{A} 1 \text { to } \mathrm{A} 4 \text { papers } \\
\text { and Fibonacci series }\end{array}$ & $\begin{array}{l}\text { Same as listed in } \\
\text { suggested strategies }\end{array}$ & $\begin{array}{l}\text {-To maintain a } \\
\text { symmetry } \\
\text { corresponding to } \\
\text { better aesthetics }\end{array}$ \\
\hline \multirow[t]{3}{*}{3} & $\begin{array}{l}\text { Composition of } \\
\text { Advertisement }\end{array}$ & & & & \\
\hline & Too much text & $\begin{array}{l}\text { Through Literature } \\
\text { review, visuals and } \\
\text { questionnaire } \\
\text { analysis }\end{array}$ & $\begin{array}{l}\text {-The advertisements } \\
\text { should be incorporated } \\
\text { with pictures so that } \\
\text { ideas can be conveyed } \\
\text { with in a very less } \\
\text { period of time }\end{array}$ & $\begin{array}{l}\text { The text or picture } \\
\text { should not cover more } \\
\text { than } 20 \% \text { of the total } \\
\text { space }\end{array}$ & $\begin{array}{l}\text { More than } 20 \% \text { of the } \\
\text { advertisement space } \\
\text { should be empty so } \\
\text { as to have a good } \\
\text { advertisement } \\
\text { composition }\end{array}$ \\
\hline & Too much picture & $\begin{array}{l}\text { Through Literature } \\
\text { review, visuals \& }\end{array}$ & Same as above & Same as above & Same as above \\
\hline \multirow[t]{2}{*}{4} & Position of device & $\begin{array}{l}\text { Through Literature } \\
\text { review, visuals \& }\end{array}$ & $\begin{array}{l}\text {-The advertisements } \\
\text { especially toilet blocks } \\
\text { or kiosk should not be } \\
\text { positioned in such a } \\
\text { manner that it should } \\
\text { be visible to motorists }\end{array}$ & $\begin{array}{l}\text { Same as listed in } \\
\text { suggested strategies }\end{array}$ & $\begin{array}{l}- \text { Position of } \\
\text { advertisement will } \\
\text { not affect the } \\
\text { motorist and passers } \\
\text { by }\end{array}$ \\
\hline & & $\begin{array}{l}\text { questionnaire } \\
\text { analysis }\end{array}$ & $\begin{array}{l}\text {-It should be } \\
\text { positioned in a area } \\
\text { which is not } \\
\text { intervened by public } \\
\text { and it should be visual } \\
\text { from a certain distance }\end{array}$ & & $\begin{array}{l}\text {-The stopping } \\
\text { distance will } \\
\text { increase, distraction } \\
\text { will decrease } \\
\text { promoting } \\
\text { advertisement in an } \\
\text { efficient manner }\end{array}$ \\
\hline 5 & $\begin{array}{l}\text { Compatibility } \\
\begin{array}{l}\text { of } \\
\text { device }\end{array} \\
\text { with } \\
\text { surroundings }\end{array}$ & $\begin{array}{l}\text { Though visuals \& } \\
\text { questionnaire } \\
\text { analysis }\end{array}$ & $\begin{array}{l}\text {-The devices should } \\
\text { be placed keeping in } \\
\text { mind the natural } \\
\text { character of place }\end{array}$ & $\begin{array}{l}\text {-Advertisement } \\
\text { spoiling the streetscape } \\
\text { should not be placed in } \\
\text { the area }\end{array}$ & $\begin{array}{l}\text { To preserve the } \\
\text { natural character of } \\
\text { the place or particular } \\
\text { land use }\end{array}$ \\
\hline 6 & $\begin{array}{l}\text { Duration } \\
\text { devices(Election } \\
\text { poster) }\end{array}$ & $\begin{array}{l}\text { Through Literature } \\
\text { review, visuals \& }\end{array}$ & $\begin{array}{l}\text {-A statute should list } \\
\text { some strict actions to } \\
\text { be taken if the period is } \\
\text { over }\end{array}$ & $\begin{array}{l}\text {-It should be removed } \\
\text { soon after contract is } \\
\text { over }\end{array}$ & \\
\hline
\end{tabular}




\section{PROPOSED PLAN OF HOARDINGS}

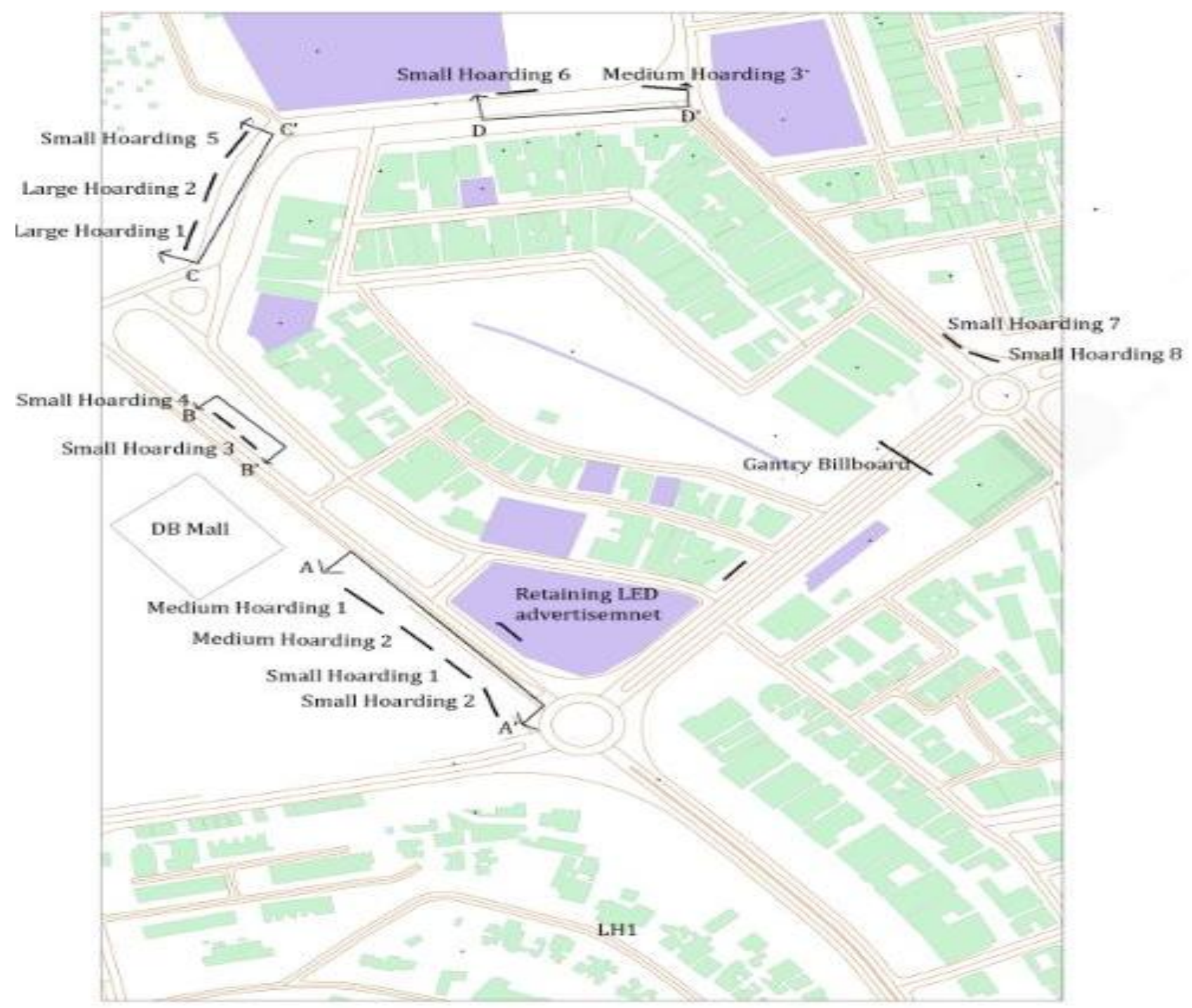

Fig 3: Proposed Plan of advertisement devices in MP Nagar Zon-1

\section{CONCLUSION}

If we talk about Indian roads similar situation is evident as far as advertisements are concerned, there are multiple advertisements are located causing visual clutter for drivers. The advertising structure should be compatible with the scale, proportion and other characteristics of the site, building or structure on which the proposed signage is to be located. Multiple advertisements on a single block of land, structure or building should be discouraged as they contribute to visual clutter. The final outcome of research is the proposed plan of advertisement devices with proper identified locations, sections, orientation and in accordance to other enlisted parameters. The planning of advertisement devices should be done ideally for any city and similar approach should be followed for proper planning of advertisement devices. The above map shows the distribution of advertisement devices. This is how MP Nagar Zone-1 will look after implementation of proper outdoor media devices

\section{REFERENCES}

[1] Anon. (2007). TRANSPORT CORRIDOR OUTDOOR, New South Wales: Publication number DP 07_033.

[2] ADY R. (1967), Investigation of the relationship between illuminated advertising signs and expressway accidents. Traffic Safety Research Review, 3, 9-11

[3] Brendan Wallace.(2003) Driver distraction by advertising: genuine risk or urban myth, 185190, Glasgow

[4] Jordaan, F., (2010), Steet Furniture: South Africa manual on advertisement control, South Africa

[5] Jordaan, F.,( 2010). Election poster: South Africa manual on advertisement control, South Africa

[6] Jordaan, F., (2010). Billboard: South Africa manual on advertisement control, South Africa

[7] MCD, (2008). Delhi Outdoor Advertisement Policy, Delhi.

[8] NMC, (2001). Nagpur Advertisement Poicy, Nagpur 
[9] NSW,(2006) Transport corridor Outdoor Advertising and signage guideline

[10] PMC,(2012).Municipal Outdoor Advertisement Bye laws, Ludhiana

[11] RUSCH USCH W, (1951), Highway accident rates as related to roadside business and advertising. Highway Research Board Bulletin, 30, 46-50.

\section{BIOGRAPHY}

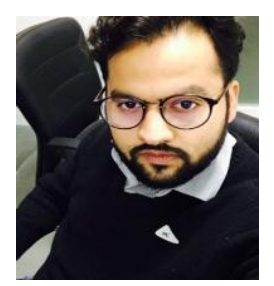

Mr. Vibhore Bakshi is currently working as an Assistant Professor in Architecture and Planning Department, Amity

University, Gurgaon 